\title{
MOGADOC: a database with 3D-structures
}

\author{
Jürgen Vogt, Evgeny Popov, Rainer Rudert, Natalja Vogt \\ From 9th German Conference on Chemoinformatics \\ Fulda, Germany. 10-12 November 2013
}

The MOGADOC database (Molecular Gas-Phase Documentation) has grown up to 11,500 inorganic, organic, and organometallic compounds, which were studied in the gas-phase mainly by microwave spectroscopy, radio astronomy, and electron diffraction. The database contains about 9,000 numerical datasets with internuclear distances, bond angles and dihedral angles. Most of the corresponding molecular structures are also given as $3 \mathrm{D}$ presentations (ball-stick-models). The retrieval features of the HTML-based database have been described elsewhere in the literature [1,2]. Some years ago a Java-applet has been developed, which enables the 3D-visualization of the molecular structures. The user can interactively rotate, shift and scale the 3D-models and can "measure" bond lengths as well bond, dihedral and elevation angles [3].

Recently new "measurement" features have been supplemented (such as for distances between centroids, angles between ring planes, etc.).

The project has been supported by the Dr. Barbara Mez-Starck Foundation.

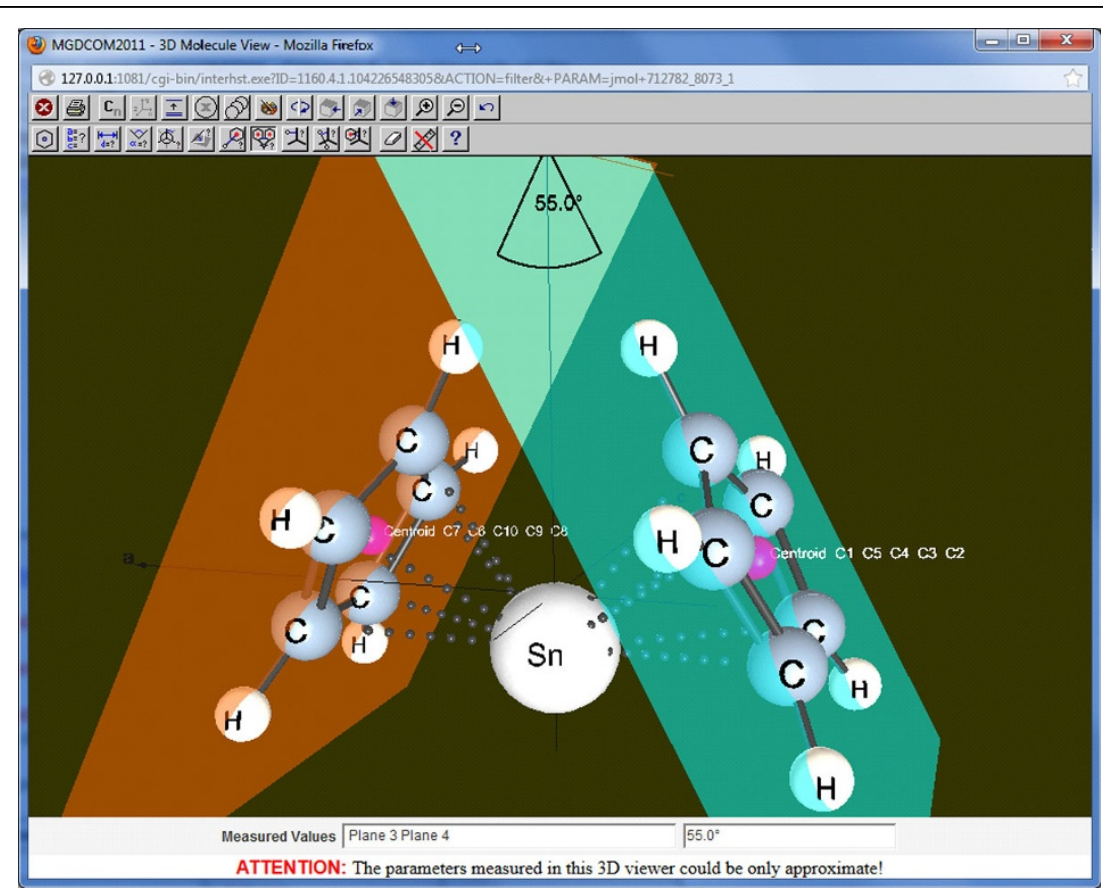

Figure 1

\footnotetext{
* Correspondence: juergen.vogt@uni-ulm.de

Chemical Information Systems, University of UIm, 89069 UIm, Germany
} 


\section{References}

1. Vogt J, Vogt N, Kramer R: Visualization and Substructure Retrieval Tools in the MOGADOC Database. J Chem Inf Comput Sci 2003, 43:357-361.

2. Vogt J, Vogt N: Structure Searching in the MOGADOC Database. $J$ Mol Struct 2004, 695:237-241.

3. Vogt N, Popov E, Rudert R, Kramer R, Vogt J: 3D Visualization of Molecular Structures in the MOGADOC Database. J Mol Struct 2010, 978:201-204.

doi:10.1186/1758-2946-6-S1-P3

Cite this article as: Vogt et al:: MOGADOC: a database with

3D-structures. Journal of Cheminformatics 2014 6(Suppl 1):P3.

\section{Publish with ChemistryCentral and every scientist can read your work free of charge}

"Open access provides opportunities to our colleagues in other parts of the globe, by allowing anyone to view the content free of charge."

W. Jeffery Hurst, The Hershey Company.

- available free of charge to the entire scientific community

- peer reviewed and published immediately upon acceptance

- cited in PubMed and archived on PubMed Central

- yours - you keep the copyright

Submit your manuscript here:

http://www.chemistrycentral.com/manuscript/<smiles>c1ccccc1</smiles>
ChemistryCentral 